\title{
MITIGATION AND ADAPTATION MEASURES IN THE HUNGARIAN RURAL DEVELOPMENT PROGRAMME
}

\author{
János Lazányi \\ University of Debrecen, Faculty of Applied Economics and Rural Development \\ 4032 Debrecen, Böszörményi str. 138, Hungary. E-mail: lazanyi@agr.unideb.hu
}

\begin{abstract}
Summary
In the Hungarian Rural Development Programme (RDP) climate change adaptation is addressed through the measures in Axis 1, 2, 3 and 4. Under Axis 1 farmers can receive support for farm modernisation that will help them adapt to climate change. The processing industry will also be able to use the available resources for capital expenditure on buildings and new equipment. Axis 2 and especially the soil and water package within the agrienvironmental measure aim to support production methods, which protect soil quality and will help adaptation to climate change. Measures of Axis 3, such as basic services for the economy and rural population, village renewal and development will provide local communities the opportunity to identify actions that can be undertaken to deal with the effects of climate change. On the other hand, the extension of forest resources contributes to climate change mitigation and enhances carbon sequestration. New methods have been elaborated to the sustainable regional water management, irrigation, water regulation, defence against internal water, and soil protection established. Water management contributes to the balance of water quantity on one side, but also to mitigating the climate change on the other.
\end{abstract}

Key words: Common Agricultural Policy, Rural Development, Climate change

\section{INTRODUCTION}

The CAP was designed in the late 1950s and introduced in the late 1960s. The official objectives, as stated in Article 33 (39) of the Rome Treaty (1958) are (i) to increase agricultural productivity by promoting technical progress and ensuring the optimum use of the factors of production, in particular labour; (ii) to ensure a fair standard of living for farmers; (iii) to stabilize markets; (iv) to assure the availability of supplies; (v) to ensure reasonable prices for consumers. The CAP resulted from the integration of member state policies, which were introduced to protect the incomes and employment of EU farmers from foreign competition and market forces. The support was assured through high import tariffs, export subsidies and fixing prices, which created stability on the EU food market. Since the integration of agriculture in the GATT/WTO system, CAP has undergone major reforms (Sckokai and Moro, 2006). The introduction of direct payments in the 1990s and the reforms of 2003 and 2008 have substantially reduced trade distortions, in particularly through the decoupling and single farm payments, which are currently applied in many member state of the EU (European Commission (2009, 2010).

With the improved integration of rural areas into the rest of the economy, non-farm incomes make up an increasingly larger share of "farm household incomes". Despite government subsidies to agriculture the employment rates dropped in Europe. OECD (2002) data show, that over the past two decades there was no positive relationship between changes in agricultural employment and changes in agricultural support in the European countries. According to Swinnen (2009), the combination of policy rent dissipation and poor targeting were the most important reasons why CAP payments have limited impact on relative farm incomes and employment. OECD studies showed that the net income effects of commodity price supports for farmers (the old CAP) were around $20 \%$, meaning that $80 \%$ of the payments went to non-farm groups, including input supplying companies and that this reduced prices to non-EU consumers and producers. Total spending on the Common Agricultural Policy has been a large share of the total EU budget. It is obvious that the EU budget review should take a close look at these allocations, which in 2009 were in excess of $€ 50$ billion and spending on direct payments was almost $€ 40$ billion (European Commission (2007, 2010). 
The special survey of Eurobarometer on agriculture and climate change pointed out that almost half the respondents believe that agriculture has already made a major contribution to combating climate change. A large majority believe that agriculture will be greatly affected by climate change over the next few years and a similar proportion of respondents agree that the EU must help farmers to change the way they work in order to combat climate change. The recognition of the fundamental role of agriculture explains the high level of support for maintaining the subsidies paid to farmers. The vast majority of people interviewed take the view that financial assistance to farmers over the next ten years should increase or remain more or less the same (Special Eurobarometer, 2009).

\section{GHG emission in Hungary}

Statistical data of the European Environmental Agency show that emissions of greenhouse gases (GHG) during the last 5-year period (2002-2006) were 31.4\% lower relative to basic year emissions. GHG emissions per capita are $7.8 \mathrm{t} \mathrm{CO} 2$-eq./cap/year, while GHG per GDP at current prices is $873.2 \mathrm{~g} \mathrm{CO}$-eq./euro. In 2006, emissions were $32 \%$ lower than the base-year level, well below its Kyoto target of $-8 \%$ for the period 2008-2012. According to projections, emissions will increase to reach a level $25 \%$ below base-year by 2010 . Hungary expects to significantly over achieve its target. The implementation of additional measures is not expected to reduce emissions. Emission in agriculture has been decreased by $41 \%$ since 1990 and represents $10.7 \%$ of total greenhouse gas emissions, which do not include emissions and removals from LULUCF and emissions from international bunkers. Emission in transport has been increased by $23 \%$ since 1990 and represents $16.1 \%$ of total greenhouse gas emissions. Energy supply and use is responsible for $60.0 \%$ and shows a slightly decreasing tendency.

In Hungary, agriculture contributes to emissions of greenhouse gases through a variety of different processes. The size of the animal husbandry is the most important factor influencing green-house gas emissions from agriculture in Hungary, where the importance of agriculture within the national economy has decreased since 1985. The loss of importance occurred not only in comparison to other economic branches, but also in terms of the absolute input-output values. Agriculture and forestry currently account for about $10 \%$ of total greenhouse gas emissions, but account for $36 \%$ of methane emissions and $67 \%$ of nitrous oxide emissions. About $86 \%$ of this methane comes from enteric fermentation in the digestive system of animals and $14 \%$ from manure management. Total emissions of methane have declined considerably over the last 20 years. Emissions from agriculture had increased until the mid 1980 s, then stabilised. Emissions have declined by about $40 \%$ over the past 20 years, mainly as a result of reduced livestock numbers. The nitrous oxide emissions arise from manures and artificial fertiliser. Agricultural emissions of nitrous oxide (N2O) have fallen slightly since the late 1980s, due to reductions in fertiliser use. Emissions of carbon dioxide are from direct energy use, such as diesel in tractors, gas to heat greenhouses, and electricity in livestock buildings. Although agriculture is directly responsible for only $1 \%$ of $\mathrm{CO} 2$ emissions, the sector can help to mitigate $\mathrm{CO} 2$ emissions through carbon sequestration in soils and timber, and by producing energy crops to replace fossil fuels. In terms of climate change mitigation, the agriculture and forestry sector is unique in having the ability to produce and to sequester greenhouse gases, as well as to provide biomass-derived renewable energy. 


\section{Mitigation activities to reduce greenhouse gas emissions in agriculture}

In general, the changes in Hungarian agriculture during the past 20 years have led to a decrease in the use of chemicals and fertilizers, fragmentation of the holdings and restoration of natural elements of the agricultural landscape, which has a positive effect on biodiversity. Investments in animal husbandry to diminish the production surplus of cereals using it as input for animal husbandry are concerned in the RDP. These increase the creation of added value along the production chain, but anaerobic digestion of slurry is a prominent renewable energy technology that has significant potential to contribute to climate change and wider environmental objectives. It helps to reduce greenhouse gas emissions by capturing methane from the decomposition of organic materials not only from slurries, but by-product of crop production; manures, waste and sewage sludge. The biogas can then be used as a renewable energy source for heat, power or as a transport fuel. Public intervention may therefore be necessary to disseminate knowledge of its potential. Without such intervention, the opportunity to achieve the public benefits expected of it may be lost.

Extension and training for the agri-food and forestry sectors is available to identify needs and directs appropriate sources of support for rural area. Such advice and training includes helping farmers adapt to the challenges of CAP reform, to review the Community Animal Health Policy, and to increase emphasis on water protection and mitigating the effects of climate change. RDP helps the agriculture and land management sector play its full part in tackling climate change. This includes promoting resource efficient farm management; examining the scope and feasibility of a market based mechanism to facilitate trading of greenhouse gas emission reductions from agriculture, forestry and other land management sectors; developing a communicational strategy to raise awareness and communicate climate change issues to land managers; exploring how environmental stewardship can make a greater contribution to achieving the Government's climate change objectives; taking forward the non-food crops strategy to substitute renewable products for those based on fossil fuels; ensuring that the development of measures under nitrates action plan also support climate change mitigation goals.

\section{Overview of the main type of climate change mitigation operations in Hungary}

Measure 121 states that agriculture in Hungary lacks compliance with animal welfare, hygiene and environmental protection requirements, and significant investments are needed in manure storage and management. Within the framework of the sub-measure 'Investments in animal husbandry', actions that can be supported include investments facilitating the storage and use of manure, including biogas facilities. However, specific actions associated with equipment for manure application, are not detailed in the RDP. Investments in equipment for better application of mineral fertilisers and manure are also not detailed. On the basis of directions in agricultural land use (arable plant production, grassland management, plantation farming and wetland management) actions can be divided into 4 sub-measures.

The integrated crop production scheme promotes rational nutrient management. The extensive grassland management scheme promotes grassland management based on animal husbandry. Under the integrated arable crop production scheme, a nutrient management plan has to be prepared and applied to find optimal land use and intensity. Actions on energysaving investments are divided between arable farming and horticulture. These investments in machinery involve strong emphasis on environmentally sound, cost-efficient and energysaving machinery and equipment, but details not given in respect of climate change mitigation. Measure 123 includes the establishment of local, small-capacity bio-ethanol plants, but the extent of energy-saving is not concerned. Organic farming and grassland management schemes promote the adoption of grassland management practices compliant with the rules and regulations of organic production in order to preserve grassland habitats of 
high natural value, while integrated production measure includes training courses offering information on sustainable farming, environmentally sound crop production technologies and organic farming.

Measure 214 includes the integrated crop production scheme, which involves rational nutrient management, integrated plant production, crop rotation and land cultivation to conserve soil. Soil conservation techniques such as reduced tillage, permanent green cover, catch crops, stubble management are also integrated in the RDP in order to conserve soils, surface and ground waters. Reduced use and/or restoration of organic soils are not in the RDP, but grassland scheme involves extensive management practices in order to preserve grassland habitats of high natural value. This national priority has also contribution to safeguarding biodiversity. The ecological requirements of RDP on large areas can be only fulfilled by developing, reorganizing, and improving agricultural management, infrastructure, reconstructing and proper establishment of the land use system. The social need for the multifunctional services of agriculture and forestry are growing and the protective and social welfare objectives have to become increasingly dominant. The measure contributes to the fulfilment of the obligation undertaken in Gothenburg in relation with the reversal of the decrease of biodiversity until 2010, to the aims of the so-called Water Framework Directive and for the aims related to the mitigation of the climate change defined in the Kyoto Protocol. RDP of Hungary integrates these measures well. Measure 214 includes a scheme for the conversion of arable lands with poor fertility into grassland, in areas threatened by floods, erosion and on land near vulnerable water resources.

Measure 216 includes establishment of grassland for environmental land use change. Within the framework of RDP, supports are granted for the first afforestation of areas to be removed from agricultural cultivation. This is based on the development and implementation of an afforestation-implementation plan. Trainings related to agriculture includes trainings related to renewable energy (the production, utilization and primary processing of biomass for energetic purposes) awareness-raising in the field of the environment, and organic farming, however climate change mitigation goals are not mentioned per se, and training details are not given. Support granted to farmers and forest holders to cover the utilization of professional advisory services, which aims to maintain of good agricultural and environmental condition. Climate change mitigation goals are not mentioned per se, but good agricultural and environmental condition may assist mitigation objectives.

\section{Adaptation to potential impacts of climate change in agriculture}

There is unequivocal evidence that the climate is changing. The effects of which on agriculture and wildlife are discernible. Drought is occurring earlier and frost later, with a consequent change in the growth cycle. It is also likely that there will be reduced availability of water in the future. Global climate change suggests a pattern of drier summers, and at the same time water consumption remains very high, especially in the Great Hungarian Plain. These problems are likely to be particularly accentuated in the Central and South East region of Hungary. Agriculture itself needs to adapt to climate change, by coping with different conditions and exploring which crops and farming systems are best adapted to the changed conditions. To improve the resilience of valuable habitats and allow species to migrate in the face of changing climate, this isolation needs to be reduced and the environmental quality of the surrounding matrix improved. Some species may benefit from climate change, but species that are already at the edge of their range may face local extinction. Climate change is also predicted to result in more frequent droughts and increased flooding, all of which will have impact upon agriculture and forestry. Land use change can contribute to the management some of these threats. Agriculture, forestry and land management can also help to mitigate climate change by reducing direct greenhouse gas emissions from the land based sectors; 
offsetting and reducing greenhouse gas emissions through providing crops as a source of renewable energy and by providing and protecting carbon stores in soils and forestry. Land management will need to adapt to the inevitable impacts of climate change. Action on adaptation within the sector may include measures to preserve biodiversity by protecting valuable habitats and species and helping them to adapt or help minimise the impacts of climate change in other sectors through water management to reduce the risk of flooding; protect livestock from impacts such as heat stress, increased risk of pests and diseases.

\section{Overview of the main type of climate change adaptation operations in Hungary}

Within the framework of the sub-measure Investments in arable farming and horticulture, actions under arable farming include the establishment and development of technology in storage and drying, while actions under horticulture include investments in environmentally sound machinery, equipment, built technology and construction. Flood prevention and management measures and preventive actions against adverse effects of climate-related extreme events are not mentioned in the RDP similarly to restoration of agricultural production potential damaged by weather extremes. Actions, under Measure 121 include establishment and reconstruction of water and energy saving irrigation plants within horticultural holdings. Actions under 125 include establishing / modernising irrigation-service work, which serves the development needs of several producers. Actions under measure 121 include development of new water-management equipment and facilities to aid delivery, distribution and control of water, while actions under 121 include investment in buildings and facilities directly linked associated with professional treatment of generated wastewater within horticultural holdings. Integrated crop production scheme promotes environmentally friendly plant production practice, which includes basic soil protection and adequate land cultivation in order to conserve soils, surface and ground waters, while measure 214 includes establishments and improved management of wetland habitat scheme. Establishment of agroforestry systems also aim to improve landscape value and biodiversity. Integrated pest management scheme includes rational nutrient management, integrated plant production, crop rotation and land cultivation to conserve soil. Plant protection activities should be carried out on the basis of documented pest forecasts and plant protection observations even in arable production. Conservation of plants and animal genetic resources also improve climate change adaptation potential. On farm plant genetic conservation of endangered vegetable and arable species by agri-environmental participants involves an increased level of support.

Trainings related to agriculture and forestry in the RDP includes farmer trainings related to the Water Framework Directive; however, details are not given, and climate change is not mentioned per se. Support granted to farmers and forest holders to cover the utilization of professional advisory services, which are aimed at regulations relating to maintenance of good agricultural and environmental condition. Climate change mitigation goals are not mentioned per se, but good agricultural and environmental condition may assist mitigation objectives.

\section{CONCLUSIONS}

The first objective of development or adaptation of agricultural infrastructures is to improve the overall performance and competitiveness of the agricultural holdings through modernization of production, and the introduction of new processes and technologies. Specific attention is given for measures to improve manure storage and manure spreading techniques and to reduce $\mathrm{N}$ emission. Efficient management of solid and liquid manure is essential for the reduction of methane emissions, originating from biological fermentation in livestock manure management. Manure management and septic pits are good examples of tangible investments in RDP, similarly to investments in spreader for better application of mineral fertilisers and manure equipment for precision farming. One of the objectives of the 
RDP based on National Agri-Environmental Programme (NAEP) is to support the development of organic farming as an environmentally-friendly method of agricultural production with economic potential. The operational objective is to ensure adequate levels of technical and economic knowledge; skills in management; product quality and safety; sustainable management of natural resources including the requirements for cross compliance, renewable energy sources and organic production. Soil and Water Protection Scheme also provides support for the introduction of sustainable crop rotations, intercropping, green cover and legumes such as beans, soybean, alfalfa and clover. Due to the expected deficit in rainfall and loss of soil fertility, the most vulnerable to climate change will be the spring crops. Extensification of pastures management, diversification of grass species help flood prevention and climate change adaptation. Conversion of agricultural land into forest and permanent pastures is also connected to soil erosion control objectives and management measures related to flood protection. Climate change mitigation is likely in training and demonstration projects.

References

European Commission, DG Agriculture and Rural Development (2009): Agricultural policy perspectives. Member States factsheets European Union, S. 10, http://ec.europa.eu/agriculture/publi/ms factsheets/2009/de en.pdf.

European Commission, DG Agriculture and Rural Development (2010): Agricultural policy perspectives. The CAP in perspective: from market intervention to policy innovation. Brief no. 1, December 2009, S. 10, http://ec.europa.eu/agriculture/publi/app-brie fs/01_en.pdf.

http://www.eea.europa.eu/themes/climate/ghg-country-profiles

Lyon, G. (2009): Draft report on the future of the common agricultural policy after 2013. Committee onAgriculture and Rural Development, 2009/2236(INI)

OECD (2002): The incidence and income transfer efficiency of farm support measures. Organization for Economic Co-Operation and Development, Paris.

Sckokai, P., Moro, D. (2006): Modelling the reforms of the Common Agricultural Policy for arable crops under uncertainty. American Journal of Agricultural Economics, 88(1), 43-56.

Serra, T., Goodwin, B. K., A. M. Featherstone (2005): Agricultural policy reform and off-farm labour decisions. Journal of Agricultural Economics, 56(2), 271-285.

Swinnen, J., de Gorter, H. (2002): On government credibility, compensation, and under-investment in public research. European Review of Agricultural Economics, 29(4), 501-522. 